\title{
ANALISIS MISKONSEPSI BUKU TEKS BIOLOGI SMA KELAS X MATERI EUBACTERIA DI KOTA KISARAN
}

\author{
Riah irawati Sihombing*, Abdul Hakim Daulae, Dian Komala Sari, Hotmaria Sihotang \\ Program studi Pendidikan Biologi, FMIPA, Universitas Negeri Medan, \\ Jl. Williem Iskandar Psr. V Medan Estate Fax. (061) 614002-613319, Medan, Indonesia, 20221 \\ *E-mail: irasihombing88@gmail.com
}

\begin{abstract}
ABSTRAK
Penelitian ini bertujuan untuk mengetahui ada atau tidaknya miskonsepsi buku teks biologi pada materi eubacteria dan mengetahui persentase (\%) kategori miskonsepsi pada materi eubacteria dari buku teks biologi SMA kelas X kurikulum 2013 di Kota Kisaran. Penelitian ini merupakan penelitian deskriptif kualitatif dengan pendekatan analisis isi. Buku teks yang dianalisis merupakan buku teks biologi SMA kurikulum 2013 yang digunakan di kota Kisaran dengan menggunakan teknik sampling jenuh. Identifikasi miskonsepsi dibagi menjadi 5 kategori yaitu undergeneralization, obsolete concept and terms, oversimplification, overgeneralization, dan misidentification. Data yang diperoleh secara deskriptif dengan menghitung frekuensi masing-masing kategori. Hasil menunjukkan bahwa buku teks A dan B yang dianalisis mengalami miskonsepsi. Kategori miskonsepsi yang ditemukan pada kedua buku teks adalah obsolete concept and terms, overgeneralization, dan misidentification. Kode buku A ditemukan miskonsepsi pada materi eubacteria. Adapun persentase kategori miskonsepsi kode buku teks A pada materi eubacteria yaitu obsolote concept and terms $100 \%$. Pada kode buku B ditemukan adanya miskonsepsi pada materi eubacteria. Adapun persentase kategori miskonsepsi buku B pada materi eubacteria yaitu obsolete concept and terms 33,33\%, overgeneralization 33,33\%, dan misidentification 33,33\%.
\end{abstract}

Kata kunci: Miskonsepsi, Buku Teks, Eubacteria, Kurikulum 2013

\section{ABSTRACT}

This study aims to know if there were misconceptions or not in biology textbooks and the percentage of each category misconception of eubacteria in biology textbook for grade $X$ senior high school based on curriculum 2013 in Kisaran. This research is a qualitative descriptive research with content analysis approach. Textbooks which analyzed are biology textbooks for senior high school curriculum 2013 and used in Kisaran by using saturated sampling technique. Identification of the misconception are divided into 5 categories namely undergeneralization, obsolete concept and terms, oversimplification, overgeneralization, and misidentification. The data obtained descriptively by calculating the frequency of each category. The results showed that misconceptions that was found in the textbooks A and B. Misconceptions categories at the textbooks found out obsolete concept and terms, overgeneralization, and misidentification. In the textbook $A$ was found on eubacteria.The percentage of misconception categories in textbook A on eubacteria was obsolote concept and terms $100 \%$. In the textbook B was found on eubacteria. The percentage of misconception category in textbook B on eubacteria was obsolete concept and terms 33,33\%, overgeneralization 33,33\%, and misidentification 33,33\%.

Keywords: Misconception, Textbook, Eubacteria, Curriculum 2013

\section{PENDAHULUAN}

Buku teks merupakan buku pegangan yang dijadikan bahan sumber informasi bagi siswa dalam proses pembelajaran yang berlangsung. Buku teks adalah buku yang berisi uraian bahan tentang mata pelajaran atau bidang studi tertentu yang disusun secara sistematis dan telah diseleksi berdasarkan tujuan tertentu, orientasi pembelajaran, dan perkembangan siswa diasimilasikan (Nugroho, 2016). Buku teks adalah buku pelajaran dalam bidang studi tertentu yang merupakan buku standar, yang disusun oleh para pakar dalam bidang masing-masing yang diperlengkapi dengan sarana-sarana pengajaran yang serasi dan mudah dipahami pemakainya. Buku teks digunakan oleh SD, SMP, SMA, dan perguruan tingkat tinggi (Tarigan, 2009). Buku teks memainkan peran yang sangat penting dalam instansi pendidikan, jika tidak ada buku yang dapat dijadikan sumber informasi maka siswa tidak akan memiliki sumber informasi yang dapat dijadikan acuan dalam menerima 
JURNAL PELITA PENDIDIKAN VOL. 5 NO. 2

Sihombing, R.I., Daulae, A.H., Komalasari, D., Sihotang, H. Halaman : $044-048$

informasi pembelajaran. Hal ini diperkuat oleh Jatmika (2014), buku memiliki peran yang besar dalam proses pendidikan sehingga buku dan pendidikan merupakan dua hal yang tak terpisahkan. Sepuluh syarat untuk memilih buku teks yang tergolong berkualitas tinggi, antara lain: (1) buku teks haruslah menarik minat siswa, (2) buku teks harus mampu memberi motivasi kepada siswa yang menggunakannya, (3) buku teks haruslah memuat ilustrasi yang menarik para siswa yang memanfaatkannya, (4) buku teks seyogyanya mempertimbangkan aspek-aspek linguistik sehingga sesuai dengan kemampuan para siswa yang memakainya, (5) buku teks isinya haruslah berhubungan erat dengan pelajaran-pelajaran lainnya, (6) buku teks haruslah dapat menstimulasi, merangsang aktivitas-aktivitas pribadi para siswa yang mempergunakannya, (7) buku teks haruslah dengan sadar dan tegas menghindari konsep-konsep yang samar-samar dan tidak biasa, (8) buku teks haruslah mempunyai sudut pandangan atau point of view yang jelas dan tegas, (9) buku teks haruslah mampu memberi pemantapan, penekanan pada nilai-nilai anak dan orang dewasa, (10) buku teks itu haruslah dapat menghargai perbedaan-perbedaan pribadi para siswa pemakainya (Tarigan, 2009). Pemberlakuan kurikulum 2013 sudah mulai dicanangkan bertahap pada tahun pembelajaran 2013/2014. Hal ini akan menuntut perubahan isi dari buku teks yang digunakan disekolah agar sesuai dengan standard kurikulum 2013. Buku teks kurikulum 2013 terkhusus pada buku teks siswa lebih ditekankan pada activity base bukan sekedar bahan bacaan, buku teks harus memuat model pembelajaran dan project yang akan dilakukan oleh siswa, serta buku teks yang ditulis mengacu pada Kompetensi Inti (KI), Kompetensi Dasar (KD), dan silabus (Wamendikbud, 2014).

Buku berbasis kurikulum 2013 untuk siswa disusun oleh pemerintah disertai dengan buku guru untuk mempermudah dalam melaksanakan kegiatan dikelas. Buku tersebut disusun berdasarkan silabus yang disusun oleh pemerintah (Karli, 2014). Tidak dapat dipungkiri bahwa dalam proses pembelajaran biologi memungkinkan siswa salah mengartikan konsep dalam menyerap informasi baik dari buku ataupun dari guru. Banyak faktor yang menyebabkan siswa mengalami miskonsepsi terhadap suatu pelajaran. Buku teks yang dijadikan satu-satunya sumber informasi bagi guru maka akan mendorong terjadinya miskonsepsi pada guru, miskonsepsi yang didapat siswa dari sekolah akan menetap pada dirinya (Odom, 1993). Bahasa yang digunakan guru dan bahasa yang digunakan didalam buku teks dapat
pISSN : 2338 - 3003

elSSN : $2502-3217$

membuat siswa kebingungan (Desmukh, 2011). Buku teks dapat menyebabkan miskonsepsi dari bahasanya yang sulit, penjelasannya tidak benar atau buku teks terlalu sulit bagi level siswa yang sedang belajar (Suparno, 2013: 46).

Ramadhan (2016), miskonsepsi menunjuk pada suatu konsep yang tidak sesuai dengan pengertian ilmiah atau pengertian yang diterima oleh para pakar. Tekkaya (2002), miskonsepsi yaitu ketidaksesuaian konsep pada buku teks dengan pengertian ilmiah atau yang diterima oleh para ilmuwan. Miskonsepsi membuat siswa sulit untuk menerima sudut pandang maupun teori dari buku teks dan tetap bertahan dalam pemahaman yang dimiliki oleh siswa (Desmukh, 2011). Miskonsepsi cenderung dapat bertahan dan miskonsepsi yang dimiliki siswa tidak mudah diubah dengan mudah selama sekolah bertahun-tahun (Yangin, et al, 2014). Miskonsepsi merupakan salah satu kekhawatiran utama dalam bidang pendidikan di dunia dan banyak penelitian dalam bidang ilmu pendidikan difokuskan pada miskonsepsi siswa (Desmukh, 2011). Berdasarkan hasil penelitian ditemukan adanya miskonsepsi pada buku teks biologi SMA. Adisendjaja (2007), menemukan bahwa buku teks biologi SMA terdapat kesalahan sebesar $17 \%$, miskonsepsi $11 \%$ dan memerlukan konsepsi alternatif sebesar $25 \%$ dari seluruh konsep. Sebanyak $25 \%$ siswa terpengaruh oleh kesalahan dan miskonsepsi yang ada didalam buku teks, miskonsepsi pada buku teks biologi SMU banyak ditemukan dari terbitan Depdikbud dan dari terbitan yang lain. Nusantari \& Abdul (2013), menemukan bahwa adanya miskonsepsi buku ajar pada materi genetika. Nugroho (2016), menemukan bahwa buku teks biologi SMA pada materi sistem pencernaan mengandung miskonsepsi. Buku teks biologi SMA pada materi sistem saraf mengandung miskonsepsi (Ramadhan, 2016). Buku teks biologi SMA kelas $X$ pada materi virus ditemukan adanya miskonsepsi (Saputri \& Widyaningrum, 2016). Dwijayanti, et al, (2016), menemukan adanya miskonsepsi buku teks biologi pada materi archaebacteria dan eubacteria. Penelitian ini dilaksanakan untuk untuk mengetahui ada atau tidaknya miskonsepsi pada buku teks biologi SMA kelas X berbasis kurikulum 2013 pada materi eubacteria di Kota Kisaran dan untuk mengetahui persentase miskonsepsi yang ada pada buku teks biologi SMA kelas X berbasis kurikulum 2013 pada materi eubacteria di Kota Kisaran. 
JURNAL PELITA PENDIDIKAN VOL. 5 NO. 2

Sihombing, R.I., Daulae, A.H., Komalasari, D., Sihotang, H. Halaman : $044-048$

\section{METODE PENELITIAN}

Penelitian ini dilakukan di SMA Kota Kisaran yang menggunakan kurikulum 2013. Waktu penelitian dilaksanakan dari bulan April hingga bulan Juni 2017. Populasi dalam penelitian ini adalah buku teks pelajaran biologi SMA kelas $X$ yang digunakan siswa dan guru di sekolah. Sampel yang digunakan dalam penelitian ini ialah buku teks biologi kelas $X$ berbasis kurikulum 2013 yang digunakan siswa dan guru di Kota Kisaran. Teknik pengambilan sampel dengan menggunakan teknik sampling jenuh. Jenis penelitian yang dilakukan adalah deskriptif kualitatif. Berupa identifikasi, klasifikasi dan analisis miskonsepsi secara deskriptif pada buku teks biologi kelas $\mathrm{X}$ materi eubacteria berbasis kurikulum 2013. Hasil dari analisis ini dibuat frekuensi miskonsepsi pada materi eubacteria dalam bentuk persentase.

Penelitian pada buku teks biologi dilakukan dengan menganalisis konsep-konsep yang ada pada materi eubacteria. Instrumen yang digunakan untuk mengidentifikasi miskonsepsi buku teks yaitu lembar instrumen identifikasi miskonsepsi dengan menggunakan pendekatan analisis isi. Indikator kategori untuk menentukan miskonsepsi pada buku teks diambil dari Hersey (2004). Indikator kategori miskonsepsi ada 5 yaitu undergeneralizations (generalisasi konsep yang terlalu sempit dari konsep literatur.), obsolete concept and terms (penggunaan istilah atau konsep yang sudah tidak digunakan lagi), oversimplifications (konsep yang terlalu disederhanakan), overgeneralizations (konsep terlalu mengumumkan atau menggeneralisasikan), dan misidentification (penjelasan konsep yang keliru atau tidak sesuai).

Adapun teknik pengumpulan data yang digunakan dalam penelitian ini ialah melakukan survei dan analisis data. Pada tahap awal dilakukan pengumpulan informasi dengan mensurvei buku-buku
pISSN : 2338 - 3003

elSSN : $2502-3217$

yang digunakan oleh siswa dan guru, kemudian mencari buku referensi sebagai perbandingan konsep yang kemudian dikembangkan menjadi lembar instrumen identifikasi miskonsepsi.

Teknik Analisis Data

Teknik analisis data dalam penelitian ini dengan menggunakan teknik analisis data deskriptif dengan menggunakan teknik distribusi frekuensi untuk memberikan deskripsi atau gambaran mengenai karakteristik yang ada pada data dalam bentuk persentase (Supardi, 2013). Adapun penghitungan persentase yang digunakan yaitu:

$$
\begin{aligned}
& \mathrm{Fr}=\frac{\mathrm{nKi}}{\mathrm{nKs}} \times 100 \% \\
& \text { Keterangan : } \\
& \mathrm{Fr}=\text { Frekuensi } \\
& \mathrm{nKi}=\text { jumlah miskonsepsi pada setiap kategori } \\
& \mathrm{nKs}=\text { jumlah keseluruhan miskonsepsi }
\end{aligned}
$$

\section{HASIL PENELITIAN}

Hasil analisis dari buku teks biologi pada materi eubacteria menunjukkan masih ada miskonsepsi. Kode buku A pada materi eubacteria masih ada ditemukan miskonsepsi. Besarnya persentase kategori miskonsepsi pada materi eubacteria yaitu obsolote concept and terms 100\%.

Besarnya persentase kategori miskonsepsi kode buku B yang ditemukan pada materi eubacteria yaitu obsolote concept and terms 33,33\%, overgeneralization $33,33 \%$ dan misidentification 33,33\%. Dari hasil keseluruhan data secara keseluruhan dari buku A dan buku B ditemukan miskonsepsi sebanyak 4. Obsolote concept and terms

\begin{tabular}{|c|c|c|c|c|c|c|c|}
\hline \multirow[t]{2}{*}{ Materi } & \multirow{2}{*}{$\begin{array}{l}\text { Kode } \\
\text { buku }\end{array}$} & \multicolumn{5}{|c|}{ Jumlah miskonsepsi pada kategori } & \multirow[t]{2}{*}{ Jumlah } \\
\hline & & $\begin{array}{l}\text { Undergene } \\
\text {-ralization }\end{array}$ & $\begin{array}{c}\text { Obsolete } \\
\text { concept and } \\
\text { terms }\end{array}$ & $\begin{array}{l}\text { Oversimplific } \\
\text {-ation }\end{array}$ & $\begin{array}{l}\text { Overgenerali } \\
\text {-zation }\end{array}$ & $\begin{array}{c}\text { Misidentifica } \\
\text {-tion }\end{array}$ & \\
\hline \multirow[t]{2}{*}{ Eubacteria } & $A$ & - & 1 & - & - & - & 1 \\
\hline & $\mathrm{B}$ & - & 1 & - & 1 & 1 & 3 \\
\hline \multirow[t]{2}{*}{ Total } & & - & 2 & - & 1 & 1 & 4 \\
\hline & & - & $50 \%$ & - & $25 \%$ & $25 \%$ & $100 \%$ \\
\hline
\end{tabular}
sebanyak 2 miskonsepsi (50\%), overgeneralization sebanyak 1 miskonsepsi (25\%), dan misidentification sebanyak 1 miskonsepsi (25\%).

Tabel 4.1 Presentase Hasil Analisis Miskonsepsi Pada Buku Kode A dan Kode Buku B 
JURNAL PELITA PENDIDIKAN VOL. 5 NO. 2

Sihombing, R.I., Daulae, A.H., Komalasari, D., Sihotang, H. Halaman : $044-048$

\section{PEMBAHASAN}

Miskonsepsi yaitu ketidaksesuaian konsep pada buku teks dengan pengertian ilmiah atau yang diterima oleh para ilmuwan (Tekkaya, 2002). Miskonsepsi sebagai pengertian yang tidak akurat akan konsep, penggunaan konsep yang salah, klasifikasi contoh-contoh yang salah, kekacauan konsep-konsep yang berbeda, dan hubungan hirarkis konsep-konsep yang tidak benar (Suparno, 2013). Berdasarkan hasil analisis buku teks biologi mengandung kategori miskonsepsi yaitu obsolete concepts and terms, overgeneralizations, dan misidentifications.

\section{Kategori Obsolete Concepts and Terms}

Obsolete concepts and terms adalah penggunaan istilah atau konsep yang sudah tidak digunakan lagi (usang). Berikut disajikan beberapa kategori yang termasuk obsolete concepts and terms: (a) Konsep pada materi eubacteria buku $A$ menyatakan bahwa dalam klasifikasi terbaru, bakteri dibagi menjadi archaebacteria dan eubacteria (bakteri sejati) (Hal 74). Konsep tersebut merupakan klasifikasi yang lama, konsep yang terbaru yaitu dengan membandingkan RNA ribosomal dan urutan lengkap genom beberapa spesies yang masih hidup saat ini, para peneliti telah mengidentifikasi dua cabang utama evolusi eukariota. Carl woese dan banyak ahli sistematika lain sekarang menggunakan pengelompokan keanekaragaman kehidupan dalam tiga domain, dimana prokariota memiliki dua domain: Arkhaea (dulu disebut arkhaebakteri) dan Bakteria (dulu disebut eubakteria) (Campbell, et al, 2003: 106). (b) Konsep pada materi eubacteria buku B menyatakan bahwa Anggota dari eubakteria adalah bakteri dan sianobakteri ( $\mathrm{Hal} 80$ ). Konsep yang terbaru ada 5 klasifikasi eubacteria berdasarkan sistematika molekuler dengan membandingkan subunit kecil RNA ribosom yaitu proteobakteri, klamidia, spirokaeta, sianobakteria, dan bakteri gram positif (Urry, et al, 2016:582-583).

\section{Kategori Overgeneralization}

Overgeneralization adalah konsep terlalu mengumumkan atau menggeneralisasikan sehingga tidak memperhatikan batas penggunaannya. Konsep pada materi eubacteria buku B menyatakan bahwa pada lingkungan yang cocok dan tersedia bahan makanan yang cukup, satu bakteri dapat membelah menjadi 2 setiap 20 menit. (Hal: 85). Konsep pembelahan sel menjadi 2 setiap 20 menit terlalu digeneralisasikan, pada hal tidak semua bakteri
pISSN : 2338 - 3003

elSSN : 2502 - 3217 mampu melakukan pembelahan sel menjadi 2 setiap 20 menit. Menurut literatur, dalam kondisi yang optimal, banyak prokariota dapat membagi setiap 1-3 jam; beberapa spesies dapat menghasilkan generasi baru hanya 20 menit (Campbell, et al, 2003:111). Hal ini juga selaras dengan penelitian yang dilakukan Dwijayanti (2016), pada buku teks biologi kelas $X$ yang menemukan adanya kategori miskonsepsi undergeneralization pada konsep bakteri dapat membelah menjadi 2 setiap 20 menit.

\section{Kategori Misidentification}

Misidentification adalah konsep yang diutarakan salah penafsiran atau salah pemahaman. Konsep pada materi eubacteria kode buku B menyatakan bahwa membran plasma bakteri tersusun dari protein dan lemak (Hal 82). Konsep yang benar menurut literatur yaitu membran plasma terdiri dari fosfolipida (yang mengandung gliserol, asam lemak dan posfat) dan protein (Volk \& Wheeler,1993: 54).

Dari hasil penelitian buku yang paling banyak mengandung miskonsepsi yaitu pada kode buku B (3 miskonsepsi). Sudah seharusnya buku teks biologi yang digunakan disekolah mengandung konsepkonsep yang benar dan diseleksi buku yang akan digunakan sebagai buku teks yang dipakai dalam proses pembelajara. Menurut Dedi Supriadi (2001), menyatakan bahwa perlu adanya seleksi dalam pemakaian buku karena pemakaian buku tanpa seleksi yang memadai dapat merugikan peserta didik.

\section{KESIMPULAN}

Hasil analisis pada buku teks biologi SMA yang digunakan di Kota Kisaran ditemukan adanya miskonsepsi pada materi eubacteria. Persentase kategori miskonsepsi kode buku A pada materi eubacteria yaitu obsolote concept and terms 100\% dan persentase kategori miskonsepsi kode buku B pada materi eubacteria yaitu obsolete concept and terms 33,33\%, overgeneralization 33,33\% dan misidentification 33,33\%.

\section{DAFTAR PUTAKA}

Adisendjaja, et al, (2007), Identifikasi Kesalahan dan Miskonsepsi Buku Teks Biologi SMU, Seminar Nasional Pendidikan Biologi, Jurusan Pendidikan Biologi FPMIPA Universitas Pendidikan Indonesia, Makalah, 1-12.

Campbell, et al, (2003). Biologi Edisi Kelima Jilid Dua, Erlangga, Jakarta. 
JURNAL PELITA PENDIDIKAN VOL. 5 NO. 2

Sihombing, R.I., Daulae, A.H., Komalasari, D., Sihotang, H.

Halaman : $044-048$

Dahar, R. W., 2006, Teori-Teori Belajar Dan Pembelajaran, Erlangga, Jakarta.

Dedi, Supriadi, (2001), Anatomi Buku Sekolah di Indonesia, Adicita Karya Nusantara, Yogyakarta.

Desmukh, (2011), Textbook: A Source Of Students' Misconceptions At The Secondary School Level, Proceedings of epiSTEME-4: Homi BhabhaCentre For Science Education, 122-126.

Dikmenli, et al, (2009), Conceptual Problem In Biology Related Topics In Primary Science And Technology Textbook In Turkey, International Journal of Invironmental \& Science Education, 4: 429-440.

Dwijayanti, et al, (2016), Analisis Miskonsepsi Archaebacteria Dan Eubacteria Dalam Buku Biologi SMA Kelas X di Kabupaten Sleman, Jurnal Pendidikan Biologi, 5: 32-42.

Hersey, D. R., (2004), Avoid Misconceptions When Teaching About Plants, www.Actionbiology.Org/Education/Hershey.

Html.

Jatmika, H. M., (2014), Analisis Kelayakan Isi Buku Teks Penjasorkes Kelas X SMA di Kabupaten Bantul Daerah Istimewa Yogyakarta, Jurnal Pendidikan Jasmani Indonesia, 10: 62-67.

Karli, Hilda, (2014), Perbedaan kurikulum tingkat satuan pendidikan 2006 dan kurikulum 2013 untuk jenjang sekolah dasar, Jurnal pendidikan penabur, 22: 84-96.

Mason, et al, (2017), Biology Eleventh Edition, McGraw Hill Education, USA.

Nugroho, F. Aulia, (2016), Identifikasi Miskonsepsi System Pencernaan Manusia Pada Buku Teks Biologi SMA Kurikulum 2013 di Kota Yogyakarta, Jurnal Pendidikan Biologi, 5: 13-22.

Odom, A. L., (1993), “Action Potentials \& Biology Textbooks: Accurate Misconseptions Or Avoidance?" The American Biology Teacher, 55: 468472

Ramadhan, N. A., (2016), Identifikasi Miskonsepsi Sistem Saraf Manusia Dalam Buku Teks Biologi SMA di Kota Yogyakarta, Jurnal Pendidikan Biologi, 5: 37-45.

Saputri \& Widyaningrum, (2016), Misconception Analysison The Virus Chapter In Biology Textbooks For High School Students Grade X, International Journal Of Active Learning. 1: 31-36.
pISSN : $2338-3003$

elSSN : $2502-3217$

Suparno, P., (2005), Miskonsepsi dan Perubahan Konsep Dalam Pendidikan Fisika. Grasindo, Jakarta.

Supardi, (2013), Aplikasi Statistika Dalam Penelitian Konsep Statistika Yang Lebih Komprehensif, Smart, Jakarta.

Tarigan, (2009), Telaah Buku Teks Bahasa Indonesia, Angkasa, Bandung.

Tekkaya, C., (2002), Misconceptions As Barrier To Understanding Biology, Journal of education, 23: 259266.

Yangin, et al, (2014), Prospective Teachers' Misconceptions About Classification of Plants And Changes In Their Misconceptions During Preservice Education, Journal Of Baltic Science Education, 3: 105117.

Urry, et al, 2016), Campbell Biology Eleventh Edition, Pearson Education Inc., USA.

Volk \& Wheeler, (1993), Mikrobiologi Dasar, Erlangga, Jakarta.

Wamendikbud R.I., (2014), Konsep dan Implementasi Kurikulum 2013, Kemendikbud, Jakarta.

Yangin, et al, (2014), Prospective Teachers' Misconceptions About Classification of Plants And Changes In Their Misconceptions During Preservice Education, Journal of Baltic Science Education, 3: 105117. 